\title{
Zhodnocení dopadů sucha v útvarech povrchových vod na vodní a vodu vázané organismy
}

\author{
MARTIN DURČÁK, MICHAL STRAKA, SVĚTLANA ZAHRÁDKOVÁ, \\ MAREK POLÁŠEK, DENISA NĚMEJCOVÁ, PETR TUŠIL, JIŘí ŠAJER
}

Klíčová slova: sucho - stav vod - ekologický stav - opatření - vodní útvar - biologické složky

\section{SOUHRN}

$\checkmark$ rámci řešení dílčího úkolu Zhodnocení dopadů sucha $v$ útvarech povrchových vod na vodní a vodu vázané organismy projektu zahrnující činnosti k podpoře výkonu státní správy v problematice sucho v roce 2016 byla zpracována zejména rešeršní analýza potenciálního vlivu sucha na jednotlivé složky a ukazatele hodnocení stavu vodních útvarů jako prostředku pro hodnocení kvality vodních ekosystémů ve smyslu směrnice 2000/60/ES [1], rešerše možných opatření pro eliminaci negativních vlivů sucha na vodní ekosystémy, návrh stupňů ohrožení suchem pro jednotlivá území Natura 2000 s vazbou na vodu, analýza druhových vlastností pro vybrané skupiny vodních organismů ve vztahu k rizikům spojeným s výskytem sucha a shrnutí možných dopadů vodních nádrží na zajištění ochrany vodních a na vodu vázaných ekosystémů.

\section{ÚVOD}

Suchem mohou být ovlivněny všechny typy vod a s nimi i druhy na vodu vázaných organismů včetně některých terestrických druhů rostlin a živočichů (např. obojživelníci, ptáci, savci), které jsou s vodou úzce spjaty - at’ už habitatově, reprodukčně, či potravně [2].

Při vysychání toků či biotopů stojatých vod dochází ke snižování výšky vodního sloupce v recipientu a může docházet až k úplné ztrátě povrchové vody. To může mít na vodní ekosystém prímé i neprrímé vlivy [3]. Prímé vlivy spočívaji ve ztrátě vody, ztrátě habitatů pro vodní organismy a v prerušení povrchového propojení se sousedními vodními biotopy. Neprímé vlivy predstavuje zhoršení kvality vody, změna potravních zdrojů a změna intenzity a struktury mezidruhových interakcí.

Při vysychání dochází ke změnám podmínek ve vodním prostředí, které mohou postupně vést až ke stavu, kdy se pro vodní organismy stává neobyvatelným. Na účinky sucha reagují dvěma nezávislými způsoby - resistencí a resiliencí. Resistencí je myšlena schopnost odolávat nepříznivým podmínkám např. ve formě semen, spor, odolných vajíček apod. Resiliencí pak schopnost vrátit se na daný biotop po zlepšení nevyhovujících podmínek. Většina vodních organismů jako reakci na sucho využívá kombinaci obou těchto schopností [4]. Při prètrvávajícím suchu dochází k oslabování významu resistence a resilience se stává stále více důležitou.

\section{VÝSLEDKY ŘEŠENÍ}

Hlavní výstupy řešení dílčího úkolu:

- Hodnocení stavu vodních útvarů podle vybraných biologických složek - pro analýzu vlivu sucha v roce 2015 na ekologický stav vodních útvarů na území celé České republiky byl použit datový soubor 3889 vzorků fytobentosu (rok odběru 2007-2015), 426 výsledků sledování makrofyt (2007-2015) a 4844 vzorků makrozoobentosu (2007-2016).

- Návrh stupñů ohrožení suchem pro jednotlivá území Natura 2000 s vazbou na vodu - byl proveden návrh stupňů relativního ohrožení hydrologickým suchem pro jednotlivá území Natura 2000 s vazbou na vodu se zohledněním životních nároků pro jednotlivé druhy živočichů, $k$ jejichž ochraně byly vymezeny, typů lokalit, kde se tito živočichové $v$ rámci chráněného území vyskytují, a zohledněním regionalizace rizika vysychání drobných vodních toků na území České republiky.

- Analýza rizik spojených s výskytem sucha pro vybrané skupiny vodních organismů - analýza byla zaměřena na druhové vlastnosti taxonů makrozoobentosu a makrofyt se zvláštním zřetelem na druhy uvedené v červeném seznamu [5, 6] a druhy zvláště chráněné podle vyhlášky č. 395/1992 Sb. a představuje ukázku možného př́istupu k hodnocení citlivosti druhů vůči vysychání. Dále byla zpracována analýza druhových vlastností zvláště chráněných druhů mihulí a ryb.

- Vliv sucha na jednotlivé složky a ukazatele hodnocení stavu vodních útvarů jako prostredku pro hodnoceni kvality vodnich ekosystémů ve smyslu směrnice 2000/60/ES - rešerše byla orientována na popis potenciálních vlivů sucha na jednotlivé biologické složky podle směrnice 2000/60/ES, popis vlivu sucha na změny habitatové diverzity $v$ tekoucích vodách, popis vlivu změn vybraných parametrů (teplota vody, nasycení kyslíkem, pH a konduktivity, průtok) na vodní organismy a popis potenciálních vlivů hydrologického sucha na chemické a fyzikálně-chemické složky podporující biologické složky.

- Možné dopady vodních nádrží na zajištění ochrany ekosystémů tekoucích vod - rešerše byla zaměřena na vlivy vodních nádrží na jakost vody $v$ tocích, hydromorfologické charakteristiky vodních toků a na biologická společenstva $v$ tocích včetně shrnutí hlavních možných dopadů na makrozoobentos, ryby a akvatickou flóru.

- Seznam vybraných prírodě blizkých opatření pro zadržení vody v krajině a jejich vliv na ekologický stav - byl zpracován přehled vybraných typů opatření pro eliminaci negativních vlivů sucha na vodní ekosystémy včetně expertního posouzení jejich vlivu na ekologický stav. 


\section{SHRNUTÍ ZÁVĚRŮ A DOPORUČENÍ}

Vlivem vysychání dochází k postupným změnám fyzikálně-chemických a chemických parametrů vody, které se následně mohou projevit i na oživení vod. Vlivem zmenšujícího se celkového objemu vody dochází ke zvyšování koncentrací některých látek (např. amoniakálního dusíku, rozpuštěných organických látek, solí atd.), naopak koncentrace rozpuštěného kyslíku ve vodě klesá (při mimořádné fotosyntetické aktivitě řasových nárostů může během dne docházet k dočasnému zvyšování). Dochází k úbytku dostupných habitatů a k prostorové izolaci refugií.

Ve stojatých vodách, obzvláště v mělčích nádržích, často dochází k rozvoji vodního květu. K rozvoji vodního květu nemusí dojít v případě, pokud je nádrž dotována vodou nezatíženou živinami a pokud nemá vnitřní zdroje živin v sedimentu. Z hlediska vztahu fytoplankton-makrofyta může být sucho spouštěčem změny alternativního stabilního stavu v mělkých nádržích směrem k dominanci fytoplanktonu i obráceně směrem $k$ dominanci makrofyt. Většina taxonů makrozoobentosu stojatých vod je schopna relativně dobře se vypořádat s důsledky období sucha, někteří zástupci dokonce vyžadují alespoň krátkodobé vyschnutí pro dokončení svého vývoje, to se však týká zejména taxonů obývajících periodické tůně. Zvýšení teploty a snížení obsahu kyslíku ve vodě se negativně projevuje na rybích populacích (obr. 1). Tento negativní vliv se nejvíce projevuje na mělkých uměle vytvořených (habitatově jednotvárných) produkčních vodách.

V tekoucích vodách dochází při vyschnutí (obr.2) k vymizení nárostů biofilmů a řas, ale po znovuzaplavení dochází velice rychle k jejich obnově. Jednotlivé druhy makrozoobentosu jsou k vysychání různě citlivé, z vodního hmyzu jsou obecně považovány za citlivější zástupci jepic, pošvatek a chrostíků, zatímco zástupci brouků nebo ploštic patři mezi relativně odolné skupiny. Pro vodní živočichy, zejména pro ryby a permanentní složku makrozooobentosu v tekoucích vodách je mimořádně důležitá migrační prostupnost, která umožňuje alespoň části populace nalézt refugia, ve kterých mohou přežít nepř́iznivé období (např. zbytkové tůně - viz obr. 3).

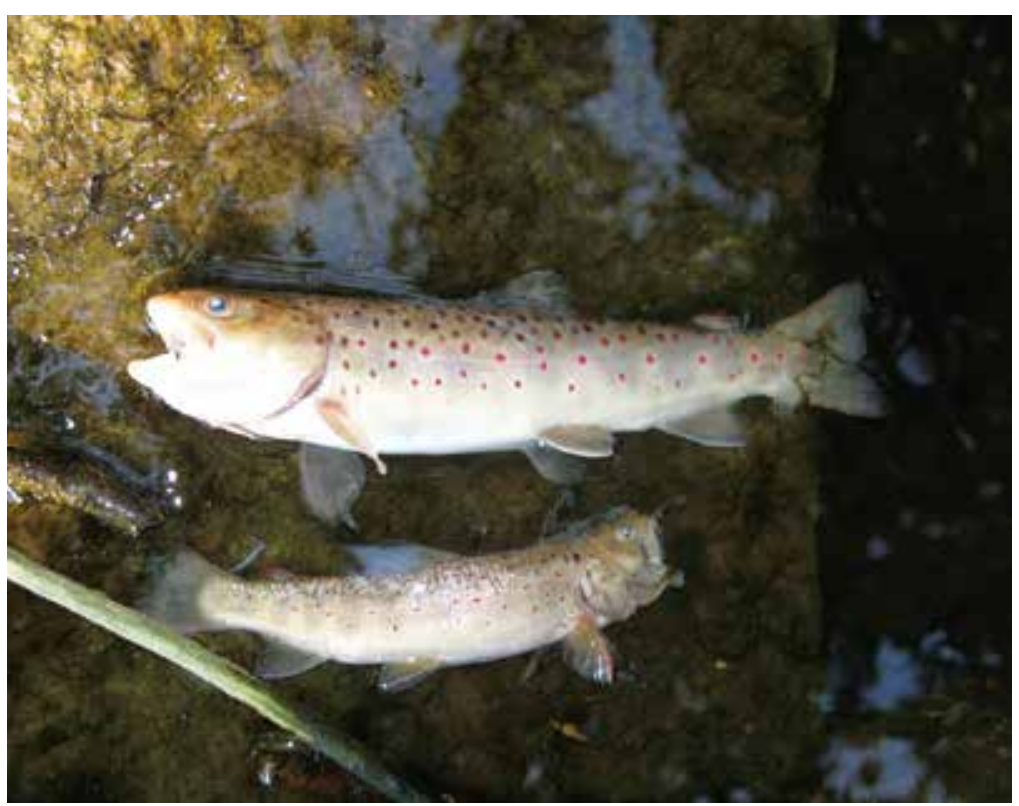

Obr. 1. Reofilní druhy ryb nejsou schopny dlouhodobě přežívat nepříznivé podmínky v izolovaných tůních; potok Kameničná (fotografie: M. Straka, 13. 8. 2015)

Fig. 1. The fish reofilic species are unable to survive the long-term adverse conditions in isolated pools; Kameničná stream (photo: M. Straka, 13. 8. 2015)

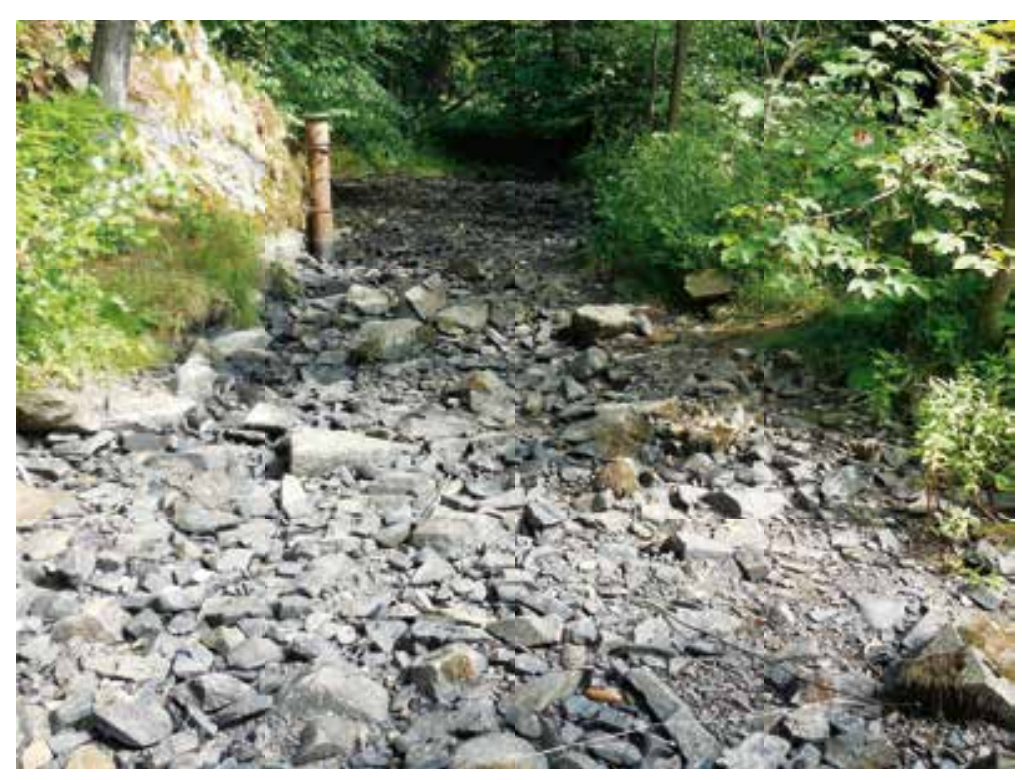

Obr. 2. Vyschlé koryto potoku Luha u Vlčí skály; Moravský kras (fotografie: D. Němejcová, 29. 7. 2015)

Fig. 2. The dry riverbed of Luha stream; Moravský kras (photo: D. Němejcová, 29. 7. 2015)

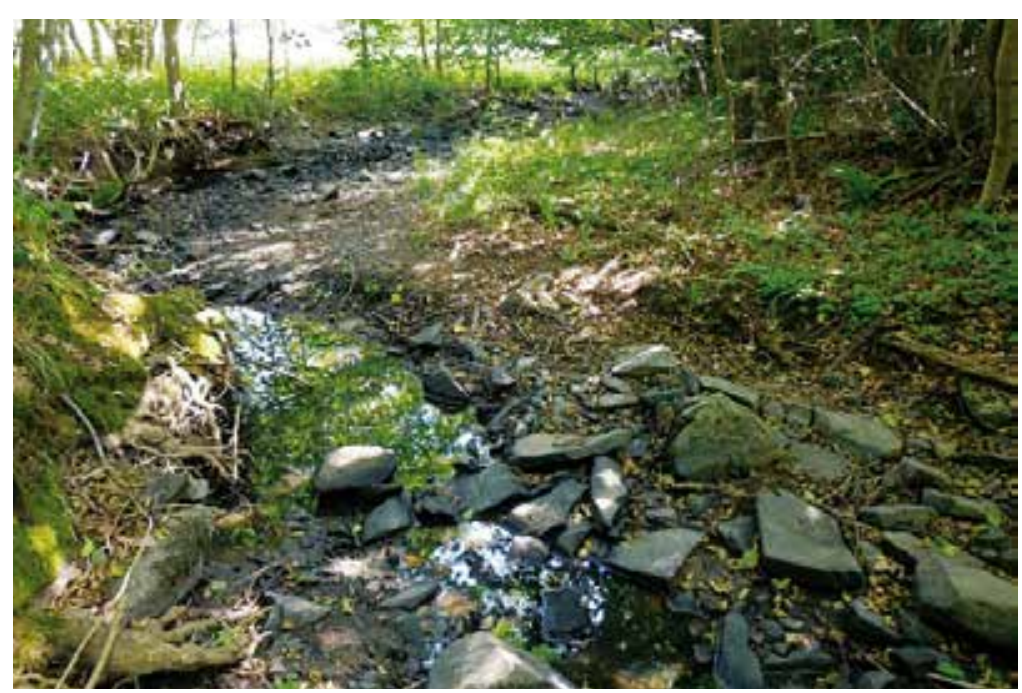

Obr. 3. Zbytkové tůně; potok Luha u Vlčí skály, Moravský kras (fotografie: D. Němejcová, 29. 7. 2015)

Fig. 3. Residual pools; Luha stream near Vlčí skála, Moravský kras (photo: D. Němejcová, 29. 7. 2015)

Prítomnost refugií je klíčovým parametrem pro resistenci a resilienci bioty téměř ve všech typech prostředí. Ta je ve stojatých i tekoucích vodách zajištěna predevším dostatečně hustou mozaikou biotopů a pestrou morfologií, tj. střídání peřejí a tůní, přirozený sedimentačně-erozní režim s prostupností do hlubších vrstev dna (hyporeálu), přirozený vegetační kryt tvořící stín a úkryty. úbytek prirozených stanovišt', stejně jako nepřirozená morfologie břehů a dna tekoucích i stojatých vod výrazně zvyšuje citlivost ekosystému vůči vysychání.

Z tohoto hlediska jsou pro stabilitu ekosystému v oblastech, které bývají postiženy suchem, důležitá revitalizační opatření zaměřená na zlepšení hydromorfologického stavu vodních toků včetně nivy. Zlepšení hydromorfologického stavu antropogenně ovlivněných vodních toků je možné dosáhnout zejména prírodě blízkou úpravou koryta a břehů, vytvářením refugií 
a odstraněním migračních bariér, zejména prríčných překážek typu jezů a hrází. Nanejvýš vhodné je využití renaturačních procesů (např. změna koryta následkem povodní po povodňovém průtoku). Součástí revitalizace/renaturace koryta toků musí být i blízké okolí (přibřežní zóna, niva). Přirozená stromová, popř. keřová, vegetace stíní volnou vodní hladinu a podporuje vytváření přiznivějšího mikroklima a tlumí denní teplotní extrémy.

Jedním z řady navrhovaných adaptačních opatření na omezení negativních dopadů sucha je často i výstavba a obnova vodních nádrží, zejména malých vodních nádrží. Umělé vodní nádrže jsou považovány za jeden z nejvýznamnějších negativních typů lidského ovlivnění fluviálních systémů. Mimo zásadní změny vlastního zaplaveného území, kde zanikají původní biotopy a vznikají biotopy s lenitickým charakterem (stojaté vody), ovlivňují nádrže závažně i úseky toků pod zátopou a do určité míry i nad ní.

Nádrže významně fragmentuji říční systémy - přerušují poproudový transport vody a sedimentů, čímž z hlediska geomorfologického indukují početné odezvy včetně agradace a siltace nad hrází a ovlivnění průtoků pod hrází. To je provázeno změnou charakteru dna, průtokového režimu a degradací toku pod hrází. Nádrže také mění teplotní a živinový režim v toku. V toku vznikají bariéry (hráz, zátopa), které organismy většinou nemohou překonat. Uvedenými vlivy a vlivy souvisejícími se závažně mění podmínky pro veškerou biotu v toku. Dochází ke změnám biologické diverzity, mění se druhové složení, namísto citlivějších druhů (specialistů) nastupuji druhy odolnější (generalisté, včetně druhů nepůvodních). Změny v taxonomickém složení jsou př́činou změn funkčních. Nejnápadněji se změny projevují na vodních bezobratlých, což je skupina nejlépe indikující změny v tekoucích vodách a která není, na rozdíl od ryb, cíleně člověkem ovlivňována.

Změny ve složení bioty vyvolané působením nádrží nejsou významné jen z hlediska ochrany prírody, ale - a to zejména - z hlediska odolnosti ekosystémů k jejich narušování a tedy i snížení poskytovaných ekosystémových služeb. Význam těchto služeb je aktuálně doceňován v důsledku projevů globální klimatické změny. Ekosystémové služby mohou být poskytovány tzv. zdravými toky, tedy těmi, jejichž stav je přirozený nebo přirozenému blízký. Degradované ekosystémy poskytují tyto služby omezeně nebo vůbec. Vyšší podíl malých vodních nádrží v povodí má také za následek zvýšené riziko vysychání drobných vodních toků se všemi důsledky pro biotu. Výstavba a obnova malých nádrží na tocích (zejména rybochovných) by neměla být, a to z hlediska jejich negativního vlivu na biologické složky ekologického stavu, podporovaným opatřením v boji proti suchu.

V rámci projektu BIOSUCHO (TA02020395) [7] byla vytvořena Metodika retrospektivní bioindikace vyschnutí toku, která umožňuje zpětně indikovat epizody vyschnutí toků na základě analýzy taxonomického a funkčního složení vzorků makrozoobentosu (vodní bezobratlí). Metodika by mohla být využita pro hodnocení úspěšnosti opatření směřujících k omezení negativních dopadů sucha na vodní toky.

Na základě analýzy dat a získaných znalostí v rámci projektu BIOSUCHO bylo zjištěno, že vyschnutí toku, tj. přerušení kontinuity vodní hladiny, může vyvolat při následném hodnocení ekologického stavu vodního útvaru na reprezentativním profilu pokles hodnoty ekologického kvalitativního poměru multimetrického indexu (EQR MMI) makrozoobentosu a způsobit i nepř́íznivý posun $\checkmark$ klasifikaci ekologického stavu.

Závislost výsledků hodnot EQR MMI makrozoobentosu a hodnot diskriminačního skóre indexu BIOSUCHO je patrná z obr. 4 - čím větší je pravděpodobnost výskytu sucha na lokalitě, tím nižší je hodnota EQR MMI.

$\checkmark$ oblastech s rizikem vysychání toků (tyto oblasti je možné identifikovat na základě Mapy rizika vysychání drobných vodních toků [7]) navrhujeme využívat výpočet indexu BIOSUCHO podle metodiky retrospektivní bioindikace vyschnutí toku, jako doplňkové k hodnocení ekologického stavu. Pokud bude tok podle vzorku vyhodnocen, že byl ohrožen vyschnutím anebo vyschl, bylo by vhodné toto uvést do výsledků hodnocení dat a správce povodí tak získá informaci o dalším prípadném riziku nedosažení dobrého ekologického stavu.

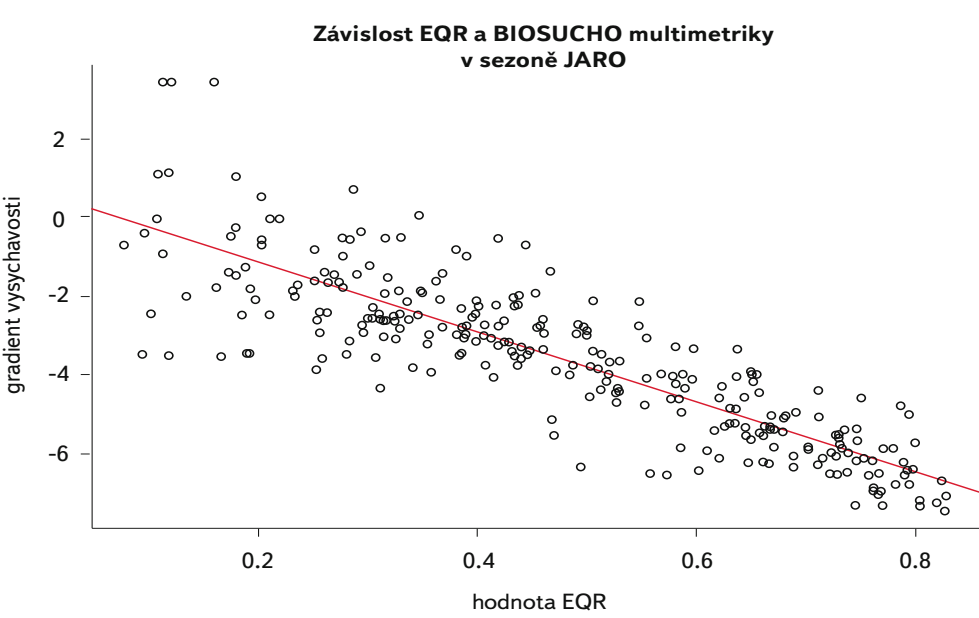

Obr. 4. Závislost hodnot EQR MMI (v grafu označeno EQR) a hodnot diskriminačního skóre indexu BIOSUCHO (v grafu označeno gradient vysychavosti) v sezoně JARO; hodnota gradientu vysychavosti stoupá s vyšší pravděpodobností výskytu sucha v předchozím období

Fig. 4. The dependence of the EQR MMI values (EQR in the chart) and the BIOSUCHO discriminatory score values (in graph - gradient of desiccation) in the SPRING season; the discriminatory score value raises with higher probability of dry phase occurence in previous period

Z výše uvedených důvodů doporučujeme pro zvládání sucha v maximální míře využít:

- plošných opatření vedoucí k vyšší retenci vody v povodích (změny hospodaření na zemědělských a lesnických plochách, obnova mokřadů a prameništ’ atd.) a současně

- opatření vedoucí k vyšší prostupnosti a diverzitě vodního prostředí (revitalizace a renaturace vodních toků, odstraňování príičných překážek v toku či obnova laterálních vodních biotopů, tedy pořičních tůní, mokřadů, podmáčených ploch či pramenných oblastí).

\section{NEJISTOTY STÁVAJÍCÍ ÚROVNĚ ŘEŠENÍ}

Dopady sucha v útvarech povrchových vod na vodní a vodu vázané organismy nebyly na území České republiky nijak intenzivně studovány a ve středoevropském prostoru existuje pouze omezené množství prací zabývajících se systematicky touto tematikou.

Obecné vlivy dopadi̊ sucha na vodní organismy, na hydromorfologii a fyzikálně-chemické a chemické parametry vodních ekosystémů jsou rámcově známé a jsou zdokumentovány a publikovány. Konkrétní datové zdroje k dopadům sucha jsou však těžko dostupné a mají mnoho různých omezení. Důležitými zdroji informací získaných na území České republiky jsou především data z Programu monitoringu povrchových vod, data z mimořádného monitoringu v suchém roce 2015 státního podniku Povodí Vltavy a výsledky projektu BIOSUCHO (TA02020395).

Data z Programu monitoringu povrchových vod umožňují nahlédnutí na vývoj ekologického stavu vodních útvarů v suchých letech, ale je třeba vytvořit dostatečný časový a finanční prostor, který umožní detailní statistickou analýzu dat ekologického stavu (biologických složek a jejich podpůrných parametrů).

Z opatření pro eliminaci negativních vlivư sucha na vodní ekosystémy je $\checkmark$ literatuře relativně dobře podložen velký význam revitalizací/renaturací vodních toků pro odolnost ekosystému vưči suchu jak v Evropě, tak i na jiných kontinentech (Austrálie, Afrika, Severní Amerika). Vliv revitalizačních a renaturačních opatření pro eliminaci negativních vlivů sucha na biologické složky 
hodnocení ekologického stavu, zejména kvantifikace pozitivního efektu těchto opatření na biologické složky, dosud na území České republiky běžně zkoumán a hodnocen není. $V$ rámci rešení dílčího úkolu jsme se potýkali s nedostatkem konkrétních naměřených dat, která bychom mohli použít pro podporu rešeršních výstupů. Dostatečně také nejsou dokumentovány samočistící procesy, které v našich tocích (a jejich dně) v období sucha probíhají.

Negativní vlivy vodních nádrží na ekosystém tekoucích vod jsou popsány v odborné literatuře a jsou dokumentovány. Datových podkladů, které dokumentuji vliv jednotlivých typů malých vodních nádrží na biotu tekoucích vod v období sucha, je k dispozici z Programu monitoringu povrchových vod poměrně málo anebo pro některé typy malých vodních nádrží úplně chybí. Výzkum vlivu malých vodních nádrží na vodní a vodu vázané ekosystémy včetně bioty v období sucha by měl být účelově podpořen. Data, která jsou již k dispozici, by měla být podrobena detailní analýze s ohledem na biotu a na procesy v toku probíhající.

Plošná opatření na zemědělské či lesnické půdě a jejich význam pro vodní faunu a flóru lze hodnotit většinou jen odborným odhadem, protože na území České republiky chybí konkrétní zkušenosti s jejich vlivem. Monitorovací profily Programu monitoringu povrchových vod se $v$ dostatečné blízkosti plošných opatření na zemědělské či lesnické půdě nevyskytují, anebo na nich nejsou monitorovány biologické složky, proto nejsou k dispozici relevantní data. I v tomto prípadě doporučujeme formou účelové podpory podpořit komplexní monitoring bioty, kvality vod, a to včetně režimu transportu sedimentů a hydrologických parametrů před realizací plošných opatření a v určitých intervalech po jejich realizaci (1 rok, 3-5 a 10 let).

Potřeba dalšího výzkumu vlivu sucha na vodní a vodu vázané ekosystémy je z výše uvedeného zřejmá. Je třeba lépe pochopit dopady sucha a následné procesy $v$ suchem postiženém toku a jeho povodí (typy bariér, způsoby rekolonizace, predace, samočištění, fyziologické změny aj.).

\section{ZÁVĚR}

Přirozené ekosystémy disponující dostatkem různorodých habitatů a dostatečnou prostupností pro migrující organismy se dokáží vyrovnávat s případnými epizodami sucha lépe než člověkem řízené umělé systémy. Zároveň mají přirozené či prírodě blízké plochy vyšší schopnost zadržovat vodu, kterou v obdobích s nedostatečnými srážkami dotuji okolní krajinu a vodní toky. Výstavba technických opatření jde často proti těmto principům a tato opatření znesnadňují vodním ekosystémům a jejich obyvatelům přirozenou obnovu a snižují schopnost čelit suchým obdobím.

\section{Poděkování}

Př́spěvek vznikl v rámci úkolů řešených pro Ministerstvo životního prostředí České republiky.

\section{Literatura}

[1] Směrnice Evropského parlamentu a Rady 2000/60/ES ze dne 23. ŕijna 2000, kterou se stanoví rámec pro činnost Společenství v oblasti vodní politiky.

[2] EDWARDS, F.K., BAKER, R., DUNBAR, M., and LAIZÉ, C. A review of the processes and effects of droughts and summer floods in rivers and threats due to climate change on current adaptive strategies. Wallingford: Centre for Ecology \& Hydrology, 2012, 75 p.

[3] LAKE, P.S. Ecological effects of perturbation by drought in flowing waters. Freshwater Biology, 48, 2013, p. 1161-1172.

[4] HERSHKOVITZ, Y and GASITH, A. Resistance, resilience and community dynamics in mediterraneanclimate streams. Hydrobiologia, 2013, 719, p. 59-75.

[5] FARKAČ, J., KRÁL, D. a ŠKORPÍK M. (eds) Červený seznam ohrožených druhů České republiky. Bezobratlí. Praha: AOPK ČR, 2005, 760 p.

[6] GRULICH, V. Red List of vascular plants of the Czech Republic: $3^{\text {rd }}$ edition. Preslia, 2012, 84, p. 631-645.
[7] ZAHRÁDKOVÁ, S. HÁJEK, O. TREML, P. PAŘlL, P. a kol. Hodnocení rizika vysychání drobných vodních toků v České republice. Vodohospodářské technicko-ekonomické informace, 2015, roč. 57, č. 6 s. 4-16. ISSN 0322-8916.

\section{Autoři}

Ing. Martin Durčák

凶martin.durcak@vuv.cz

Mgr. Michal Straka, Ph.D.

凶michal.straka@vuv.cz

doc. RNDr. Světlana Zahrádková, Ph.D.

凶svetlana.zahradkova@vuv.cz

Mgr. Marek Polášek

凶marek.polasek@vuv.cz

RNDr. Denisa Němejcová

$凶$ denisa.nemejcova@vuv.cz

Ing. Petr Tušil, Ph.D., MBA

凶petr.tusil@vuv.cz

Ing. Jiří Šajer

凶jiri.sajer@vuv.cz

Výzkumný ústav vodohospodářský T. G. Masaryka, v. v. i.

\section{EVALUATION OF THE IMPACTS OF DROUGHT ON AQUATIC AND WATER-BOUND ORGANISMS IN SURFACE WATER BODIES}

\section{DURCAK, M.; STRAKA, M.; ZAHRADKOVA, S.; POLASEK, M.; NEMEJCOVA, D.; TUSIL, P.; SAJER, J.}

TGM Water Research Institute, p. r. i.

Keywords: drought - water status - ecological status measures - water body - biological quality elements

Within the framework of the sub-task "Evaluation of the impacts of drought on aquatic and water-bound organisms in surface water bodies" a project involving activities to support the state administration in the drought issue in 2016 was prepared mainly a review of the potential impacts of drought on individual elements and indicators of water status assessment as a means of assessing the quality of aquatic ecosystems within the meaning of Water Framework Directive 2000/60/ EC, the search for possible measures to eliminate the negative effects of drought on aquatic ecosystems, the design of drought levels for individual Natura 2000 areas, selected taxonomical groups of aquatic organisms in relation to the risks associated with drought and a summary of possible impacts of water reservoirs to ensure the protection of aquatic and water-bound ecosystems. 